Review / Derleme

\title{
Minimally invasive management of esophageal perforation
}

\author{
Özofagus perforasyonunun minimal invaziv tedavisi \\ Atilla Eroğlu ${ }^{\circledR}$, Yener Aydın ${ }^{1}$ ', Ömer Yılmaz ${ }^{2}{ }^{2}$ \\ 'Department of Thoracic Surgery, Medicine Faculty of Atatürk University, Erzurum, Turkey \\ ${ }^{2}$ Department of Gastroenterology, Medicine Faculty of Atatürk University, Erzurum, Turkey
}

\begin{abstract}
Esophageal perforation is a medical emergency associated with high morbidity and mortality. There is no consensus on the optimal treatment of this life-threatening condition. Conventional treatment of esophageal perforation is surgical. However, more recently, endoscopic treatment has become the treatment of choice given its less invasive nature compared to surgical treatment. This includes endoscopic clip administration, endoscopic stent placement, endoscopic suturing, endoscopic vacuum therapy and tissue sealants which are all administered via the endoluminal route. Whilst small defects $(<2 \mathrm{~cm})$ may be closed with endoscopic clips, larger defects require stent placement or suturing. Removable esophageal stent is an effective method of treatment in cases with esophageal perforation as they allow minimal invasive repair of perforation and rapid nutrition. Endoscopic suturing can be used both to fix the stent to prevent migration and to primarily close the perforation. If perforation is associated with a mediastinal collection, drainage is mandatory and this procedure can be performed by computed tomography guided percutaneous drainage, thoracoscopy or endoscopic vacuum therapy. In some cases, a combination of these minimally invasive methods is required. Since endoscopic methods provide better quality of life and outcomes and shorten length of hospitalization, such methods have become the treatment of choice for esophageal perforation.
\end{abstract}

Keywords: Clip; endoscopy; esophagus; esophageal perforation; perforation; stent; thoracoscopy.

Esophageal perforation is a rare condition associated with high mortality and morbidity risk. Historically, esophageal perforation has been treated by surgical methods. However, nowadays, conservative therapy and endoscopy have an

\section{$\ddot{O} Z$}

Özofagus perforasyonu yüksek morbidite ve mortalite ile karakterize acil bir durumdur. Hayatı tehdit eden bu durumun uygun tedavisi konusunda kesin bir fikir birliği bulunmamaktadır. Geleneksel olarak özofagus perforasyonunun tedavisi cerrahidir. Bununla birlikte, endoskopik tedavi cerrahiden daha az invaziv ve daha az morbid olarak günümüzde primer tedavi seçimidir. Endoskopik klip uygulaması, endoskopik stent yerleştirilmesi, endoskopik sütür, endoskopik vakum tedavisi ve doku yapıştırıcıları endolüminal yoldan uygulanmaktadır. Küçük defektler $(<2 \mathrm{~cm})$ endoskopik klipler ile kapatılabilir. Daha büyük defektler stent yerleştirilmesi veya sütür gerektirir. Çıkartılabilir özofagus stenti, perforasyonun minimal invaziv onarımına ve hizlı beslenmeye izin vermesiyle özofagus perforasyonu olan olgularda etkili bir tedavi yöntemidir. Endoskopik sütür hem migrasyonu önlemek için stentin sabitlenmesi hem de perforasyonun primer olarak kapatılması için kullanılabilir. Perforasyon bir mediastinal koleksiyon ile ilişkili ise, drenaj zorunludur ve bu işlem bilgisayarlı tomografi rehberliğinde perkütan drenaj, torakoskopi veya endoskopik vakum tedavisi ile yapılabilir. Bazı olgularda bu minimal invaziv yöntemlerin kombinasyonu gerekir. Endoskopi merkezli minimal invaziv yöntemlerin daha iyi yaşam kalitesi ve sonuçlar sağlaması ve hastanede yatış süresini kısaltması nedeni ile özofagus perforasyonunda tedavi seçiminde bu yöntemlere doğru bir yönelim gözlenmektedir.

Anahtar sözcükler: Klip; endoskopi; özofagus; özofagus perforasyonu; perforasyon; stent; torakoskopi.

important place among treatment modalities. In recent years, interventional endoscopy, an effective but less invasive method, has been developed as an alternative to primary surgery. There are several techniques to restore the continuity of the gastrointestinal system,

Received: September 27, 2017 Accepted: November 07, 2017

Correspondence: Yener Aydın, MD. Atatürk Üniversitesi Tıp Fakültesi Göğüs Cerrahisi Anabilim Dalı, 25240 Yakutiye, Erzurum, Turkey. Tel: +90 442 - 3448439 e-mail: dryeneraydin@hotmail.com 
to prevent and treat the infection associated with perforation, to empty the potential collection, and to provide nutritional support. ${ }^{[1]}$ In this study, the areas of use and outcomes of minimally invasive methods were evaluated in the literature for the treatment of esophageal perforation.

\section{Incidence}

It is highly difficult to determine the true incidence of esophageal injuries. Whilst the most common cause of esophageal injuries was spontaneous, iatrogenic injuries have taken the first place as therapeutic interventions are becoming increasingly more common. While the risk of esophageal injury is $0.018-0.003 \%$ in flexible endoscopies, it is $0.11 \%$ for rigid esophagoscopes, and it can be up to $10-15 \%$ if therapeutic interventions are considered. ${ }^{[2]}$

\section{Etiology}

Esophageal injuries can be divided into two groups, intraluminal and extraluminal. Factors involved in the etiology of esophageal injuries are shown in Table 1.

\section{Clinical Findings}

Initially, clinical findings of esophageal injuries are obscure, and they usually become evident after 24 hours. In the initial hours of perforation, unless there is an accompanying complication such as pneumothorax or subcutaneous emphysema, the physical examination might be without any pathology. This is particularly more common in patients with iatrogenic perforation with no oral intake. In case of oral intake hours, days after the perforation, the patient may present with signs of sepsis.
Symptoms and physical examination findings vary based on the cause, localization and time of occurrence of the perforation. The most frequent symptoms are pain, fever, dysphagia, dyspnea and subcutaneous emphysema. In thoracic perforation, mediastinal emphysema is in the forefront, and subcutaneous emphysema is detected in $30 \%$ of the cases. ${ }^{[2,3]}$ While pain is the most common symptom, it is non-specific. While fever points to a possible systemic inflammatory response and a possible onset of infection, it is not specific. A rapid rise in and high levels of fever are indicators of toxic progression and seen after mediastinal perforation. Spontaneous rupture of the esophageal often presents with severe chest pain, dyspnea, hematemesis, nausea, sweating and rigors. ${ }^{[2]}$

\section{Diagnosis}

Early diagnosis of esophageal perforation is established by determination of clinical findings and radiological confirmation of these findings. Direct X-ray provides important clues for the diagnosis of esophageal perforation in $70-90 \%$ of the cases. ${ }^{[2,4]}$ Signs such as hydrothorax, pneumothorax, hydropneumothorax, pneumomediastinum, subcutaneous emphysema, mediastinal dilation, subdiaphragmatic air, foreign matter, and retrotracheal dilation can be detected. Mediastinal emphysema is present in approximately half of esophageal perforations. Hydropneumothorax is detected in one quarter of the cases. ${ }^{[5,6]}$

Esophagography is necessary in all cases of esophageal perforation to confirm diagnosis, to localize perforation and for treatment. In cases of perforation in lower esophageal section secondary to instrumentation,

Table 1. Etiology of esophageal injury

\begin{tabular}{lc}
\hline A- Intraluminal injuries & B- Extraluminal injuries \\
\hline 1- Instrumental & 1- Penetrating injuries \\
Esophagoscopy & Gunshot wounds \\
Esophageal bougienage & Stab wounds \\
Pneumatic dilation & Iatrogenic perforation \\
Endoesophageal tube & Foreign bodies erosion \\
Biopsy & \\
Sclerotherapy & \\
Endotracheal tube & \\
2- Non-instrumental & 2- Blunt injuries \\
Barotrauma & Traffic accident \\
Caustic injuries & Fall from height \\
Medicines & Cardiopulmonary resuscitation \\
Infections & 3- Operative trauma \\
3- Foreign bodies &
\end{tabular}


contrasting agent is frequently seen to extravasate the pleural space or mediastinum. Following water-soluble contrast esophagography, if there are still suspicions or exact anatomic localization cannot be obtained, the procedure can be repeated with barium. However, many surgeons are worried of the extravasation of barium into thorax. The use of water-soluble agents can detect $75 \%$ of thoracic perforations. ${ }^{[7]}$

Tomographic assessment using contrasting agent is another option for diagnosis. Pneumothorax, pneumomediastinum, subcutaneous emphysema, mediastinal dilation, abscess cavities, lesion level and, if present, foreign matter can be seen in computed tomography (CT). In some cases, CT may even detect very small extravasations of contrasting agent which cannot be detected by standard X-rays. Emphysematous tissue planes and any emerging abscess can be clearly demonstrated by CT. Additionally, it helps to detect the vertical invasion of an infectious process in the mediastinum. ${ }^{[4,8]}$

The gold standard diagnosis of rupture is by visualization by endoscopy. Both the level of the rupture and accompanying diseases are detected, and the treatment method is decided by esophagoscopy. However, the use of endoscopy in the diagnosis of esophageal perforation is controversial. Small perforations might be missed even by experienced endoscopists. Also, entering into the laceration area by endoscope may enlarge the perforation even more, and additional contamination may occur. ${ }^{[6]}$

\section{The Goals of Treatment}

There are two basic goals in the treatment of perforation. The first is the restoration of the esophageal lumen. The second is the control of extraluminal contamination to prevent sepsis. In addition, proper hemodynamic monitorization, support and systemic antibiotic therapy are essential.

\section{The Choice of Treatment}

The successful completion of the treatment of esophageal perforation is associated with several factors including the time period elapsed between rupture and diagnosis, the place and size of the rupture, the degree of contamination, and the general status of the patient In fact, the period elapsed from perforation to diagnosis is the most important factor affecting the outcome of esophageal perforation. ${ }^{[9]}$ As there is no single strategy to sufficiently overcome many of these conditions, the optimal treatment of perforation is unclear.

Conventional treatment of thoracic and abdominal perforation is by primary repair of the perforation with an emergency surgical approach in cases without underlying esophageal pathology or long-term inflammation. While there is data recommending the early repair of perforation, persistent leak occurs and additional esophageal interventions might be necessary in approximately $30 \%$ of repairs. ${ }^{[9]}$

\section{Operative Treatment}

For many years, it was accepted that aggressive surgical approach is mandatory for the treatment of esophageal perforation. These operative approaches are drainage only, decortication and drainage, primary repair with or without tissue aid, controlled fistula formation with T-tube, esophageal resection or esophageal exclusion. ${ }^{[10]}$ The choice of the operative approach is based on the hemodynamic status of the patient, the presence of coexisting pathologies, and the suitability of esophageal muscle and mucosa layer for primary repair. While many authors advocate the repair of the perforation area with supportive tissue in early stages, primary repair was not recommended in cases who were admitted later on in the disease process. In many series and reviews, it was emphasized that treatment within the first 24 hours is associated with successful outcomes. ${ }^{[5,6,10]}$

In perforations with large mediastinal or pleural contamination, operative treatment is more frequently necessary. Boerhaave syndrome and large iatrogenic perforations have more possibility to benefit from operative treatment. Operative mortality rate varied between $0 \%$ and $80 \%$ in a meta-analysis between 1990 and 2003 , and mean mortality rate was reported to be $18 \%{ }^{[11]}$ In more recent series, mortality rate is between $2 \%$ and $20 \%$, and lower than $10 \%$ in most series. ${ }^{[12-14]}$

While many authors advocate the open surgical treatment for esophageal perforations, other authors obtained excellent results with non-operative treatment of perforation and percutaneous control of mediastinal sepsis. ${ }^{[5,6,15,16]}$ When self expanding covered stents started to be used in both benign perforations and anastomotic leakage, the treatment of esophageal perforation started to shift to minimally invasive methods. $^{[9,17]}$

\section{Minimally Invasive Surgery with Thoracoscopy}

The purpose of the surgery is to provide sufficient closure of the defect to allow esophageal healing, and to remove esophageal content from thorax, mediastinum and peritoneal space. In cases with mediastinal and pleural contamination, even if endoscopic closure is considered for the treatment of perforation, thoracoscopy should also be added for mediastinal 
debridement and drainage. Thoracoscopic repair of esophageal perforation causes less trauma in patients. The purpose of the surgery is to provide sufficient closure of the defect to allow esophageal healing, and to wash esophageal content from thorax, mediastinum and peritoneal space.

In selected patients with acute esophageal perforation, minimally invasive surgery is increasingly being used mostly for stable patients with mild contamination. The literature reports are mostly limited to case reports and small case series explaining the treatment of Boerhaave syndrome and perforation caused by balloon dilation in achalasia, summarizing the thoracoscopic and laparoscopic approaches. ${ }^{[10]} \mathrm{Cho}$ et al ${ }^{[18]}$ reported 15 cases with Boerhaave syndrome treated by thoracoscopy or thoracotomy based on the surgeon's experience. Operation period, ventilation period and mortality rate in seven cases in the thoracoscopy group were lower. According to this study, regardless of the time elapsed from perforation to the treatment, thoracoscopic esophageal repair might be a decent alternative in cases with Boerhaave syndrome who are relatively stable or have moderate inflammation. Fiscon et al. ${ }^{[19]}$ combined thoracoscopic treatment and endoscopic treatment in a case with Boerhaave syndrome.

\section{Endoscopic Treatment}

Endoscopic treatment is being used increasingly for the treatment of perforation in cases who are diagnosed early with no sign of sepsis. Endoscopic approach can also be applied in perforated cases with ongoing incomplete treatment. The ability to combine both diagnosis and treatment obviously increases the utility of endoscopy. The rate of endoscopic assessment and treatment was 37\% in between 1990 and 1994, and increased to $80 \%$ in between 2005 and 2009. ${ }^{[20]}$

\section{Endoscopic Clips}

Endoscopic clips are currently the only endoluminal device which can be used to close a mucosal defect associated with acute esophageal perforation. There are two types of clips approved by Food and Drug Administration (FDA), and it is possible to close small perforations with them. Immediately diagnosed small iatrogenic perforations are candidates to assess the placement of endoscopic clip. In some cases, clips and stents can be used together.

\section{Through-The-Scope (TTS) Clips}

Standard through-the-scope clips were initially designed for hemostasis. Later, the design of TTS clips were developed, and nowadays, started to be used for the closing of iatrogenic perforations. ${ }^{[21]}$ Through-the-scope clips can be used to close perforations smaller than $2 \mathrm{~cm}$ provided that the surrounding tissue is viable and feasible. If the tissue surrounding the defect is inflamed or endured, clip application might be difficult. Each clip has different deployment mechanism, and endoscopist and assistant should be familiar with them. It is recommended to approach from the most distal part with the first clip. Starting from distal side prevents accidental loosening of the clips during closure. As this method is new, there is limited data on the successful use of clips for the closure of esophageal perforation. ${ }^{[22-24]}$

\section{Over-The-Scope Clips (OTSC)}

In December 2010, a newer and bigger clip system called OTSC (Ovesco Endoscopy, Campbell, CA, USA) was approved by FDA. A single application of OTSCs may provide full thickness closure of open defects up to $2-3 \mathrm{~cm}$. The design of this device, usually known as "bear-claw", is different from the design of TTS clips. The advantage of OTS over TTS clips is the ability to close long-term leakages and fistulas even if the surrounding tissue is inflamed or endured. This is possible as OTS devices have more pressure force and tissue grip. Transparent applicator cap is mounted on the tip of endoscope. Clip is made of a biocompatible material, nitinol, and can stay in the body for long-term. The caps are available in three sizes, $11 \mathrm{~mm}, 12 \mathrm{~mm}$ and $14 \mathrm{~mm}$, which are compatible with almost all endoscopes on the market. During the approach, caps with two different depths are available to grip the tissue more or less. Clips are available in three sizes adapted based on the cap sizes. There are three different types of teeth compatible with different tissues and indications including traumatic, atraumatic and gastrostomy closure. While atraumatic clip is preferred to control the bleeding, traumatic clip is mostly used to close fistula and perforations. ${ }^{[10]}$

A successful full thickness closure was initially demonstrated in an animal experiment. ${ }^{[25]}$ Later, many clinical trials reported that this device was successfully applied for the full thickness closure of perforation, leakage and fistula. ${ }^{[26,27]}$ Haito-Chavez et al. ${ }^{[28]}$ reported successful technical and clinical closure of the defect in all 188 patients by OTSC. Esophageal fistula was present in 16 of these cases, leakage in five, and perforation in 10. Similarly, Kirschniak et al. ${ }^{[29]}$ reported $100 \%$ success rate for the closure of esophageal perforation by OTSC. While high success rates are reported, it should be remembered that it might be difficult to grip and fold the edges of the perforation if the perforation is large and necrotic. 
The closure of perforations with a diameter of more than $20 \mathrm{~mm}$ might be difficult due to the size of the clip and more than one clip might be necessary. ${ }^{[1]}$

\section{Esophageal Stent Placement}

Esophageal stents were initially used for palliative purposes in the early years of 1990s. Since then, partially covered and nowadays fully covered stents are used for benign indications. Later, esophageal stents were started to be used for the closure of perforation and anastomotic leakage. The biggest advantage of stent placement is the immediate control of perforations, maintaining the esophageal wall during mucosal healing, the possibility of early oral nutrition and the prevention of stricture formation. ${ }^{[30-32]}$ Recently, for the treatment of esophageal perforation, surgical intervention rate has been decreased and stent placement has increased significantly.

\section{Self Expandable Plastic Stents}

Self expandable plastic stent (SEPS) is an effective, safe, and relatively non-invasive method of treatment for esophageal fistula and perforations. Polyflex (Boston Scientific, Natick, MA, USA) stents are the most commonly used SEPSs for this purpose. In order to prevent migration, it is made from polyester completely covered with silicon with increasingly expanding proximal end. Self expandable plastic stents have high level of efficacy in the treatment of esophageal leakage and perforations. They have some advantages over metal stents in the treatment of esophageal perforation: they provide a safe and effective force to close soft material leakage and prevent silicon membrane tissue ingrowth. This allows easy repositioning of the stent and stent removal. However, the placement of SEPS is more difficult and the rate of migration is higher. ${ }^{[24,33,34]}$

In many studies, SEPSs are removed within 28 days. The most frequent complication is stent migration, seen in $8-23 \%$ of cases at short-term follow-up and approximately in $40 \%$ of cases at long-term follow-up. ${ }^{[24,33,34]}$ High migration rate of the stent was associated with the smooth external surface of the polyflex stent and absence of obstruction in leakage area. This complication may be prevented by using stents with wider diameters or fixing the stent edge onto esophageal wall by means of endoscopic clips. $^{[24]}$

\section{Self-Expandable Metallic Stents}

Self-expandable metallic stents (SEMSs) have been developed to treat malignant obstructions. However, nowadays, with the development of partially covered, fully covered and removable stents, their indications of use were widened. There are several important functions of fully covered SEMS placement in esophageal perforations. Stent covers the perforation and removes the esophageal content from perforation area. Thereby, oral intake can be reinitiated easily, and contamination of extraluminal structures is prevented. Stent also provides re-epithelization for the tissue. Partially covered SEMS contains $1.5 \mathrm{~cm}$ of uncovered segment on the proximal and distal ends. This helps the stent to fit into its place and the prevention of migration. Nevertheless, the removal of partially covered SEMS might be difficult, and placement of a second stent might be necessary. ${ }^{[21]}$ Fully covered stents are ideal to control leakage. However, the possibility of migration is higher with these. Appropriate drainage of the leakage area and particularly perforation is highly important. Placement of a fully covered stent prevents the leakage from the esophageal wall, but this may also hinder the sufficient drainage of the cavity and may cause sepsis. Freeman et al. ${ }^{[35]}$ reported four factors affecting the unsuccessful stent placement and decreased efficacy for the treatment of leakage. These include leakage on the proximal cervical esophageal, passage of stent through gastro-esophageal junction, an esophageal injury of $>6 \mathrm{~cm}$, and anastomotic leakage associated with a more distal conduit leakage.

In a retrospective study, van Boeckel et al. ${ }^{[36]}$ evaluated the usability of fully covered SEMS, partially covered SEMS and SEPS in 52 cases with benign esophageal rupture and anastomic leakages. A total of 83 stents were placed in 52 cases (61 partially covered SEMSs, 15 fully covered SEMSs, and seven SEPSs). Endoscopic stent removal was successful in all cases. While stent migration is mostly seen in fully covered SEMSs (20\%), the migration rate was $14 \%$ in SEPSs and $10 \%$ in partially covered SEMSs. Tissue ingrowth and overgrowth were only seen in cases with partially covered SEMSs (11\%). It was reported that covered stents that were placed for a period of five-six weeks for the treatment of benign esophageal perforation or anastomotic leakages might be an alternative to surgery. It was reported that there is no difference in efficacy between partially covered SEMSs, fully covered SEMSs and SEPSs; therefore, stent choice should be made based on the expected stent migration risks (SEPS and fully covered SEMS) and tissue overgrowth or ingrowth (partially covered SEMS).

\section{Endoscopic Suturing}

Endoscopic suturing techniques allow larger defects to be closed. Endoscopic sutures have been used to close both acute perforations and chronic fistulas. However, it is more difficult than clip 
application as a technique. System provides the tissues to be pulled to each other by full thickness sutures. Device requires a two-channel therapeutic endoscope. Tissue closing and suture placement might be facilitated by a holding forceps pulling the tissue back. During the procedure, auxiliary parts may be placed through the working channel of the endoscope. The OverStitch Endoscopic Suturing System (Apollo Endosurgery, Austin, USA) allows interrupted or continuous suturing. Also, fixation of the stent onto esophageal wall may be established by endoscopic suture. ${ }^{[24]}$

Ngamruengphong et al. ${ }^{[37]}$ compared migration rates between 44 cases who had endoscopic suturing for stent fixation and 81 cases who did not have endoscopic suture in a multicenter study performed in 125 cases. Stent migration was detected substantially in cases with no usage of endoscopic suture (33 vs. $16 \%, \mathrm{p}=0.02$ ).

Contrary to OTSC, the size of the perforation does not prevent closing. In a total of 13 cases with defects sized $25 \mathrm{~mm}$ to $50 \mathrm{~mm}$, successful primary closing was reported using this method for the esophageal perforation. ${ }^{[38]}$

\section{Endoscopic Vacuum Assisted Closure}

Endoscopic vacuum assisted closure (EVAC) is a new technique for the drainage of mediastinal collections. ${ }^{[21]}$ In acute esophageal perforation, appropriate drainage of the extraluminal contamination is necessary for a successful treatment modality. Drainage procedure may be performed by open or minimally invasive surgery or interventional radiology. In addition to that, recently, EVAC sponge system started to be used for the treatment of perforation as it was used to close soft tissue defects. While this approach is mainly used for chronic fistulas, it was also thought to be used for acute esophageal perforation. ${ }^{[10]}$

In the literature, the largest series on EVAC use belongs to Laukoetter et al. ${ }^{[39]}$ with 52 cases. While 39 cases had anastomotic leakage, 13 cases had esophageal perforation, and $94 \%$ success rate was reported. Brangewitz et al. ${ }^{[0]}$ compared 39 patients who were treated using SEMP or SEPS with 32 patients who were treated with EVAC for the treatment of intrathoracic esophageal leakage. In a multi-variable analysis, successful wound closure was found to be independently associated with EVAC treatment. The closure rate of the leakage in EVAC group (84.4\%) was found to be significantly higher compared to SEMS/SEPS group (53.8\%). They reported that EVAC is a more effective method of treatment than stents for the closure of intrathoracic leakages.

\section{Tissue Sealants}

The most common tissue sealants in clinical practice are fibrin glue and cyanoacrylate. Fibrin glue is most effective when applied on dry area; it requires the endoscopic removal of tissue residue and pus. It is applied via double lumen catheter to form a fibrin cover on leakage area. Cyanoacrylate has antibacterial properties and can be applied on an infected area. Usually, before applying the tissue sealant, the mucosa surrounding the gap is deepitheliazed by a cytology brush to facilitate the healing of the fistula. ${ }^{[24]}$ Tissue sealants may be used stand alone or together with other various techniques. Kotzampassi and Eleftheriadis ${ }^{[41]}$ reported $96.8 \%$ clinical and technical success rate using tissue sealants in 63 cases with anastomotic leakage.

\section{Hybrid Procedures}

In order to minimize the morbidity and mortality for the treatment of esophageal treatment, endoscopic or radiological techniques are combined with minimally invasive or open surgery. This development may include interventional radiological techniques to place thoracic or mediastinal drains in cases with loculated abscess or undrained fluid collection after primary repair. Alternatively, thoracoscopic or laparoscopic techniques can be used for drain placement or decortication. Thoracoscopic drainage can be combined with endoscopic methods such as stent or clip. Today, the popularity of combining endoscopic treatment and minimally invasive surgical treatment based on the time of diagnosis and status has increased. Currently, hybrid procedure is most frequently performed as primary repair or thoracoscopic drainage performed with endoscopic stent placement. ${ }^{[10]}$

In conclusion, minimally invasive methods accelerate the recovery of patients and decrease the period of hospitalization, patient morbidity, and costs. More accurate diagnosis and less invasive treatment reduce the morbidity and mortality to more acceptable levels. Endoscopic treatment should be considered for stable patients with smaller perforations which are contained or well drained. Even long-term esophageal fistulas resulting from perforation can be closed with endoscopic treatment. In cases with excessive contamination and large uncontained perforation, surgical treatment can be combined with endoscopic procedures. As endoscopic and radiologic therapeutic techniques are being developed day by day, hybrid procedures combining treatment methods will be more 
common. These minimally invasive methods can be easily applied in experienced thoracic surgery clinics, and in a near future, a consensus on the treatment of esophageal perforation can be established.

\section{Declaration of conflicting interests}

The authors declared no conflicts of interest with respect to the authorship and/or publication of this article.

\section{Funding}

The authors received no financial support for the research and/or authorship of this article.

\section{REFERENCES}

1. Di Leo M, Maselli R, Ferrara EC, Poliani L, Al Awadhi S, Repici A. Endoscopic Management of Benign Esophageal Ruptures and Leaks. Curr Treat Options Gastroenterol 2017;15:268-84.

2. Eroglu A, Aydin Y, Yilmaz O. Thoracic perforations-surgical techniques. Ann Transl Med 2018;6:40.

3. Pasricha PJ, Fleischer DE, Kalloo AN. Endoscopic perforations of the upper digestive tract: a review of their pathogenesis, prevention, and management. Gastroenterology 1994;106:787-802.

4. Faggian A, Berritto D, Iacobellis F, Reginelli A, Cappabianca S, Grassi R. Imaging Patients With Alimentary Tract Perforation: Literature Review. Semin Ultrasound CT MR 2016;37:66-9.

5. Eroglu A, Can Kürkçüogu I, Karaoganogu N, Tekinbaş C, Yimaz O, Başog M. Esophageal perforation: the importance of early diagnosis and primary repair. Dis Esophagus 2004;17:91-4.

6. Eroglu A, Turkyilmaz A, Aydin Y, Yekeler E, Karaoglanoglu N. Current management of esophageal perforation: 20 years experience. Dis Esophagus 2009;22:374-80.

7. Foley MJ, Ghahremani GG, Rogers LF. Reappraisal of contrast media used to detect upper gastrointestinal perforations: comparison of ionic water-soluble media with barium sulfate. Radiology 1982;144:231-7.

8. Fadoo F, Ruiz DE, Dawn SK, Webb WR, Gotway MB. Helical CT esophagography for the evaluation of suspected esophageal perforation or rupture. AJR Am J Roentgenol 2004;182:1177-9.

9. Ben-David K, Behrns K, Hochwald S, Rossidis G, Caban A, Crippen $\mathrm{C}$, et al. Esophageal perforation management using a multidisciplinary minimally invasive treatment algorithm. J Am Coll Surg 2014;218:768-74.

10. Carrott PW Jr, Low DE. Advances in the management of esophageal perforation. Thorac Surg Clin 2011;21:541-55.

11. Brinster CJ, Singhal S, Lee L, Marshall MB, Kaiser LR, Kucharczuk JC. Evolving options in the management of esophageal perforation. Ann Thorac Surg 2004;77:147583.

12. Vallböhmer D, Hölscher AH, Hölscher M, Bludau M, Gutschow C, Stippel D, et al. Options in the management of esophageal perforation: analysis over a 12 -year period. Dis Esophagus 2010;23:185-90.
13. Keeling WB, Miller DL, Lam GT, Kilgo P, Miller JI, Mansour KA, et al. Low mortality after treatment for esophageal perforation: a single-center experience. Ann Thorac Surg 2010;90:1669-73.

14. Minnich DJ, Yu P, Bryant AS, Jarrar D, Cerfolio RJ. Management of thoracic esophageal perforations. Eur J Cardiothorac Surg 2011;40:931-7.

15. Vogel SB, Rout WR, Martin TD, Abbitt PL. Esophageal perforation in adults: aggressive, conservative treatment lowers morbidity and mortality. Ann Surg 2005;241:1016-21.

16. Ben-David K, Lopes J, Hochwald S, Draganov P, Forsmark C, Collins D, et al. Minimally invasive treatment of esophageal perforation using a multidisciplinary treatment algorithm: a case series. Endoscopy 2011;43:160-2.

17. van Boeckel PG, Sijbring A, Vleggaar FP, Siersema PD. Systematic review: temporary stent placement for benign rupture or anastomotic leak of the oesophagus. Aliment Pharmacol Ther 2011;33:1292-301.

18. Cho JS, Kim YD, Kim JW, I HS, Kim MS. Thoracoscopic primary esophageal repair in patients with Boerhaave's syndrome. Ann Thorac Surg 2011;91:1552-5.

19. Fiscon V, Portale G, Fania P, Duodeci S, Frigo F, Migliorini G. Successful minimally invasive repair of spontaneous esophageal perforation. J Laparoendosc Adv Surg Tech A 2008;18:721-2.

20. Kuppusamy MK, Hubka M, Felisky CD, Carrott P, Kline EM, Koehler RP, et al. Evolving management strategies in esophageal perforation: surgeons using nonoperative techniques to improve outcomes. J Am Coll Surg 2011;213:164-71.

21. Saxena P, Khashab MA. Endoscopic Management of Esophageal Perforations: Who, When, and How? Curr Treat Options Gastroenterol 2017;15:35-45.

22. Coda S, Antonellis F, Tsagkaropulos S, Francioni F, Trentino P. Complete endoscopic closure (clipping) of a large esophageal perforation after pneumatic dilation in a patient with achalasia. J Laparoendosc Adv Surg Tech A 2012;22:815-8.

23. Rokszin R, Simonka Z, Paszt A, Szepes A, Kucsa K, Lazar G. Successful endoscopic clipping in the early treatment of spontaneous esophageal perforation. Surg Laparosc Endosc Percutan Tech 2011;21:311-2.

24. Rogalski P, Daniluk J, Baniukiewicz A, Wroblewski E, Dabrowski A. Endoscopic management of gastrointestinal perforations, leaks and fistulas. World J Gastroenterol 2015;21:10542-52.

25. von Renteln D, Schmidt A, Vassiliou MC, Rudolph HU, Caca K. Endoscopic full-thickness resection and defect closure in the colon. Gastrointest Endosc 2010;71:1267-73.

26. Nishiyama N, Mori H, Kobara H, Rafiq K, Fujihara S, Kobayashi M, et al. Efficacy and safety of over-the-scope clip: including complications after endoscopic submucosal dissection. World J Gastroenterol 2013;19:2752-60.

27. Ferreira AO, Lopes J, Velosa J. Snapper fishbone esophageal perforation closed with an over-the-scope-clip. BMJ Case Rep 2013;2013: bcr2013201614.

28. Haito-Chavez Y, Law JK, Kratt T, Arezzo A, Verra M, Morino $\mathrm{M}$, et al. International multicenter experience 
with an over-the-scope clipping device for endoscopic management of GI defects (with video). Gastrointest Endosc 2014;80:610-22.

29. Kirschniak A, Subotova N, Zieker D, Königsrainer A, Kratt T. The Over-The-Scope Clip (OTSC) for the treatment of gastrointestinal bleeding, perforations, and fistulas. Surg Endosc 2011;25:2901-5.

30. Eroğlu A, Aydın Y, Altuntaş B, Türkyılmaz A. Treatment of complications caused by metallic stent placement in esophageal cancer. Turk Gogus Kalp Dama 2016;24:703-10.

31. Turkyilmaz A, Eroglu A, Aydin Y, Kurt A, Bilen Y, Karaoglanoglu N. Complications of metallic stent placement in malignant esophageal stricture and their management. Surg Laparosc Endosc Percutan Tech 2010;20:10-5.

32. Turkyilmaz A, Aydin Y, Eroglu A, Bilen Y, Karaoglanoglu N. Palliative management of esophagorespiratory fistula in esophageal malignancy. Surg Laparosc Endosc Percutan Tech 2009;19:364-7.

33. Moyes LH, Mackay CK, Forshaw MJ. The use of selfexpanding plastic stents in the management of oesophageal leaks and spontaneous oesophageal perforations. Diagn Ther Endosc 2011;2011:418103.

34. Hünerbein M, Stroszczynski C, Moesta KT, Schlag PM. Treatment of thoracic anastomotic leaks after esophagectomy with self-expanding plastic stents. Ann Surg 2004;240:801-7.

35. Freeman RK, Ascioti AJ, Giannini T, Mahidhara RJ. Analysis of unsuccessful esophageal stent placements for esophageal perforation, fistula, or anastomotic leak. Ann Thorac Surg 2012;94:959-64.
36. van Boeckel PG, Dua KS, Weusten BL, Schmits RJ, Surapaneni N, Timmer R, et al. Fully covered selfexpandable metal stents (SEMS), partially covered SEMS and self-expandable plastic stents for the treatment of benign esophageal ruptures and anastomotic leaks. BMC Gastroenterol 2012;12:19.

37. Ngamruengphong S, Sharaiha RZ, Sethi A, Siddiqui AA, DiMaio CJ, Gonzalez S, et al. Endoscopic suturing for the prevention of stent migration in benign upper gastrointestinal conditions: a comparative multicenter study. Endoscopy 2016;48:802-8.

38. Sharaiha RZ, Kumta NA, DeFilippis EM, Dimaio CJ, Gonzalez S, Gonda T, et al. A Large Multicenter Experience With Endoscopic Suturing for Management of Gastrointestinal Defects and Stent Anchorage in 122 Patients: A Retrospective Review. J Clin Gastroenterol 2016;50:388-92.

39. Laukoetter MG, Mennigen R, Neumann PA, Dhayat S, Horst G, Palmes D, et al. Successful closure of defects in the upper gastrointestinal tract by endoscopic vacuum therapy (EVT): a prospective cohort study. Surg Endosc 2017;31:2687-96.

40. Brangewitz M, Voigtländer T, Helfritz FA, Lankisch TO, Winkler M, Klempnauer J, et al. Endoscopic closure of esophageal intrathoracic leaks: stent versus endoscopic vacuum-assisted closure, a retrospective analysis. Endoscopy 2013;45:433-8.

41. Kotzampassi K, Eleftheriadis E. Tissue sealants in endoscopic applications for anastomotic leakage during a 25-year period. Surgery 2015;157:79-86. 